Сазонець І. Л., д.е.н., професор (Національний університет водного господарства та природокористування, м. Рівне),

Джинджоян В. В., к.е.н., доцент (ВНПЗ «Дніпровський гуманітарний університет», м. Дніпро)

\title{
НАПРЯМИ РЕАЛІЗАЦІЇ СОЦІАЛЬНИХ СКЛАДОВИХ ДІЯЛЬНОСТІ ТУРИСТИЧНИХ ПІДПРИЕМСТВ
}

у статті розглянуто напрями реалізації соціальних складових діяльності туристичних підприємств, серед яких авторами визначено наступні: соціальний розвиток трудових колективів туристичних підприємств; розширення спектру туристичних послуг, які носять соціальний характер, в т.ч. освітній, медичний (лікувальний), культурноісторичний туризм, туризм для дітей; приєднання туристичних компаній до ініціатив сталого розвитку.

Ключові слова: напрями; туристичні; підприємства; соціальний; послуги; сталий розвиток.

Постановка проблеми. Питанням дослідження соціальної складової в розвитку туристичних підприємств приділяється недостатньо уваги. Разом 3 тим ця проблема $€$ актуальною та багатоаспектною. Перший аспект проблеми реалізації складових базується на вдосконаленні організації діяльності туристичної компанії та відносин всередині трудового колективу. В туристичних підприємствах, як і в будь-яких інших підприємствах, повинні працювати механізми соціального захисту та розвиватися програми корпоративної соціальної відповідальності.

Інший аспект реалізації соціальних складових в діяльності туристичних підприємств - це надання туристичних послуг, які мають соціальне спрямування. В нашій роботі, спираючись на дослідження вітчизняних авторів та свої попередні напрацювання, ми відносимо до цих видів послуг такі туристичні продукти, як туризм, пов'язаний із лікуванням та оздоровленням населення, набуттям освіти, підвищенням кваліфікації, ознайомчий туризм, що розширює пізнання людини в галузі історії та культури, мовні програми та тури. Окремими напрямом такого туризму є дитячий туризм, який практично завжди несе в собі соціальну функцію. Слід визначити, що соціальність окремих туристичних програм, особливо в сфері дитячого туризму, зумовлюється державним, грантовим їх фінансуванням. Нині ці форми фінансування не мають таких масштабів, як у роки планової 
економіки, але продовжують існувати та набувати нові форми.

Окремим напрямом соціальної складової діяльності туристичних підприємств є їх діяльність у середовищі корпоративної підтримки цілей сталого розвитку. Ідеї, програми сталого розвитку, спрямовані на покращення екології, зменшення екологічних та техногенних ризиків, роблять туризм більш привабливим в цілому та на їх основі створюються окремі туристичні програми. Крім того, туристичні підприємства, приєднуючись до таких ініціатив, беруть участь у збереженні довкілля. Ініціативи сталого розвитку завжди спрямовані на покращення якості життя людей, а у нашому випадку - на покращення якості туристичних послуг, якості дестинацій, продовження тривалості життя, покращання здоров'я. Програми сталого розвитку несуть в собі значну соціальну складову, тому вони $€$ особливим видом соціальної діяльності туристичних підприємств.

Аналіз досліджень i публікацій. Дослідження проблеми визначення напрямів реалізації соціальних складових діяльності туристичних підприємств містить у собі елементи багатокомпонентного та мультидисциплінарного дослідження. Значна кількість вчених досліджує проблеми діяльності туристичних підприємств з точки зору поширення спектру послуг, виявлення напрямів диверсифікації туристичних продуктів, інформатизації туристичного бізнесу. Проблеми соціальної складової в діяльності туристичних підприємств досліджували такі науковці, як Бондаренко М.П., Ганкіна М.С., Гарбера О.Є., Гороховська К.В., Грищенко О.Ф., Івченко Л.О., Мешко Н.П., Мухін В.С., НезвещукКогут Т.С., Редько В.Є., Самойлова І.І., Узунов Ф.В. Вони робили соціальні аспекти в дослідженні різних сфер діяльності туристичних підприємств, але необхідно проведення комплексного дослідження в цьому напрямі.

Невирішені раніше частини загальної проблеми. Основною ланкою туристичного бізнесу $\epsilon$ туристичні підприємства, однак туристичний бізнес - це сукупність підприємств сфери обслуговування і ряду виробничих служб окремих територій, які спеціалізуються на задоволенні рекреаційних потреб населення. Соціальна діяльність туристичних підприємств відбивається у низці функцій. Головною соціальною метою туризму $\epsilon$ збільшення тривалості та поліпшення якості житя людини. Поєднання соціальної спрямованості та прибутковості діяльності $\epsilon$ невирішеною проблемою науки про туризм.

Постановка завдання. Для розвитку туристичних підприємств у напрямі забезпечення реалізації їх соціальних функцій в перспективі повинні бути вирішені наступні завдання: формування сучасної 
нормативно-правової бази визначення i впровадження нових технологій; надання економічної та юридичної інформації, прагнення до подальшої інтеграції у всесвітнє туристичне співтовариство; формування у широкої громадськості країни чіткого уявлення про важливість значення туризму як пріоритетного напрямку економіки; налагодження партнерства між урядом країни та місцевими органами влади.

Основні результати дослідження. Нині уряд України обговорює низку законопроєктів і законотворчих ініціатив, спрямованих на збільшення розміру гарантій туристських організацій, що працюють у сфері виїзного туризму. На нашу думку, ці закони, в разі їх прийняття, актуалізують пріоритети розвитку туристичних підприємств та їх соціальної діяльності в таких напрямах:

- вдосконалення нормативно-правової бази для створення сприятливих організаційно-правових умов розвитку туризму і рекреації;

- інформаційно-рекламна політика і просування регіонального туристичного продукту для формування привабливого образу регіону як туристичного центру та збільшення потоку туристів в область;

- розвиток туристично-рекреаційної інфраструктури та підвищення за рахунок цього інвестиційної привабливості регіону;

- підтримка і розвиток пріоритетних і затребуваних на ринку видів туризму, сприяння диверсифікації пакета туристських послуг;

- розширення міжнародного та міжрегіонального співробітництва в сфері туризму, інтеграція в український і міжнародний туристичний ринки, входження в міжнародні (європейські) туристські маршрути;

- вдосконалення регіональної системи підготовки, перепідготовки та підвищення кваліфікації туристських кадрів;

- соціальний розвиток трудових колективів туристичних підприємств;

- розширення спектру туристичних послуг, що носять соціальний характер, в т.ч. освітній, медичний (лікувальний), культурноісторичний туризм, туризм для дітей;

- приєднання туристичних компаній до ініціатив сталого розвитку.

В статті Бондаренко М.П. «Проблеми розвитку туристичних ринків» визначено обмежувальні чинники розвитку туристичних підприємств, серед яких автор визначає і соціальні чинники (табл. 1). 
Характеристика обмежувальних чинників розвитку туристичних підприємств [1]

\begin{tabular}{|c|c|c|}
\hline № & Група чинників & Характеристика чинників \\
\hline 1 & $\begin{array}{l}\text { Інституціонального } \\
\text { характеру }\end{array}$ & $\begin{array}{l}\text { Недосконалість законодавчої бази; відсутність } \\
\text { на місцях альтернативи планів розвитку } \\
\text { туристичних територій; відсутність місцевих } \\
\text { органів влади в розвитку галузі; тиск з боку } \\
\text { контролюючих органів; низька якість оснащення } \\
\text { та незадовільний стан аварійно-рятувальних } \\
\text { пунктів; наявність злочинних схем виведення } \\
\text { земель зі статусом природоохоронної зони; не } \\
\text { завжди прозорі та заплутані схеми виділення } \\
\text { земельних ділянок для будівництва споруд } \\
\text { рекреаційного призначення; відсутність } \\
\text { уніфікованої звітності }\end{array}$ \\
\hline 2 & $\begin{array}{l}\text { Природоохоронного } \\
\text { характеру }\end{array}$ & $\begin{array}{l}\text { Перезавантаженість популярних дестинацій; } \\
\text { недостатність засобів та важелів впливу з метою } \\
\text { покращення навколишнього середовища; } \\
\text { збільшення рівня забруднення та екологічного } \\
\text { навантаження пропорційно збільшенню } \\
\text { туристичних потоків; чутливість до впливу } \\
\text { природних явищ, зміни клімату та екологічного } \\
\text { стану }\end{array}$ \\
\hline 3 & $\begin{array}{l}\text { Економічного } \\
\text { характеру }\end{array}$ & 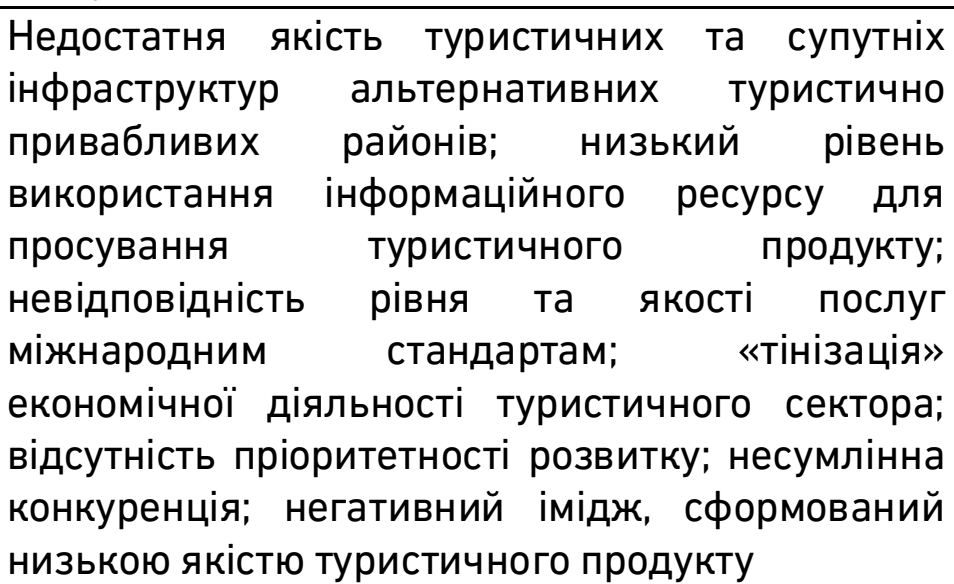 \\
\hline 4 & $\begin{array}{l}\text { Соціального } \\
\text { характеру }\end{array}$ & $\begin{array}{l}\text { Брак кваліфікованої робочої сили; низька якість } \\
\text { соціального забезпечення впливу туризму на } \\
\text { стан зайнятості; знищення культурної та } \\
\text { історико-архітектурної спадщини; низька } \\
\text { культура туристів; мовні бар'єри }\end{array}$ \\
\hline
\end{tabular}

До обмежувальних чинників соціального характеру автор відносить наступні: брак кваліфікованої робочої сили; низька якість 
соціального забезпечення впливу туризму на стан зайнятості; знищення культурної та історико-архітектурної спадщини; низька культура туристів; мовні бар'єри. Крім того автор окремо визначає чинники природоохоронного характеру, які за своєму суттю несуть в собі елементи соціального впливу. Такий вплив мають чинники природокористування як на окрему людину, так і на соціуму цілому.

Тому і для розвитку туризму природоохоронні чинники несуть соціальний зміст, що виражається зокрема в таких проблемах, як рівень захворювання, тривалість життя, харчова безпека, здоровий спосіб життя та інше [1, С. 87-91].

Соціальна діяльність запровадження туристичних послуг підприємствами повинна спиратися на розвинуту інфраструктуру, яка також повинна враховувати елементи соціального характеру. Так, Узунов Ф.В. в роботі «Управління розвитком державно-приватного партнерства в реальному секторі: на прикладі туристичної галузі України» визначає головні проблеми сучасної інфраструктури туризму, які, на його думку, полягають у відсутності:

- орієнтованої на широкі верстви населення пропозиції готелів, туристично-готельних комплексів, туристичних баз;

- системи туристичних маршрутів для всіх вікових груп населення, орієнтованих на різні рівні доходів населення;

- розвиненої системи туристично-екскурсійних бюро в кожному регіоні [2, С. 125].

Таким чином, ми можемо підкреслити думку автора про необхідність вирівнювання соціальних можливостей отримання туристичних послуг людей різного віку, людей з різним рівнем доходів та представників різних соціальних груп.

Соціальні чинники діяльності туристичних підприємств $\epsilon$ основою для підвищення їх конкурентоспроможності. Соціальні чинники поширені у формуванні інноваційних переваг діяльності туристичних підприємств. Професор Мешко Н.П. в роботі «Особливості управління попитом в туристичному бізнесі» наголошує, що «для розвитку конкурентних переваг туристичному підприємству необхідні інноваційні технології створення туристичного продукту». Впровадження інноваційних технологій вирішує за їі думкою такі питання:

- формування інноваційної складової в туристичних продуктах і послугах (нові види послуг, нестандартні засоби мотивації, нестандартні туристичні продукти та ін.);

- ефективне використання вже вкладених коштів, зниження витрат на обслуговування і перерозподіл ресурсів з метою досягнення 
відповідності сучасним вимогам бізнесу;

- розширення можливостей клієнтів, при цьому синхронізуючи процеси маркетингу, продажів, логістики та надання послуг;

- модернізація управління маркетинговими ресурсами, ведення більш цілеспрямованого інтерактивного діалогу 3 клієнтами 3 використанням цифрових, соціальних і традиційних маркетингових каналів;

- інтеграція соціальних інструментів у свій бізнес;

- створення єдиного середовища для спілкування та спільної роботи, якою легко управляти і зручно користуватися [3].

Авторка визначає, що соціальні чинники діяльності туристичних підприємств можуть стати значним резервом збільшення попиту на туристичну послугу. До таких чинників вона відносить інтеграцію соціальних інструментів туристичних підприємств в свій бізнес. Як відомо, до соціальних інструментів (або інструментів соціальної політики) відносять такі форми розвитку бізнесу, як фінансові трансфери, додаткові права або пільги, спеціальні штрафи, додаткові послуги, різноманітні субсидії, окреме ставлення до вразливих верств населення, інформаційні інструменти.

Розглядаючи можливості вдосконалення системи регулювання діяльності туристичних підприємств на основі поширення практики державно-приватного партнерства Узунов Ф.В. пропонує цілу низку заходів. Серед них, на нашу думку, основними є:

- управління розвитком державно-приватного партнерства в галузі туризму;

- розробка і внесення на розгляд уряду (й інших органів державної влади) пропозицій з управління попитом на туристичні послуги всередині країни на базі моніторингу і розрахунків коефіцієнтів туристичної активності в регіонах;

- розробка моделей партнерства в діяльності підприємства (фінансовий, організаційно-правовий аспект);

- розробка державної програми реалізації проєктів туристичними підприємствами;

- збір, класифікація і систематизація проєктів партнерства туристичних підприємств та держави у галузі туризму на основі встановлених критеріїв;

- оцінювання інвестиційної привабливості проєктів фахівцями туристичних підприємств та регіональних органів влади;

- організація і проведення конкурсів серед підприємств на отримання державної підтримки;

- координування і регулювання поточного стану проєктів; 
- консультації щодо вибору підприємств-партнерів і побудови системи партнерських взаємовідносин;

- надання консалтингових послуг для партнерів у державному i приватному секторах (наприклад, консультації з розробки проєктів партнерства у галузі туризму; приведення їх у відповідність зі встановленими критеріями; пошук, вибір організаційно-правової форми співробітництва; обґрунтування i залучення джерел фінансування);

- сприяння організації і розвитку структур і філій туристичних підприємств в регіонах;

- навчання і підвищення кваліфікації учасників проєктів партнерства на базі філій, залучених для цієї мети організацій;

- розробка реєстру державної власності у галузі туризму [2, C. 126].

Перераховані чинники державно-приватного партнерства містять в собі можливості розвитку соціальної складової туристичних підприємств. До таких складових ми можемо віднести: наявність інституційних чинників в діяльності туристичних підприємств, які $€$ важливим фактором регулювання соціальної спрямованості туристичних програм, посилення стабільності політико-правового середовища діяльності туристичних підприємств, що зменшує ризики в діяльності туристичних підприємств не відповідно, зменшує загрози для клієнтів компаній, суспільства в цілому, пропорційний розподіл можливостей туристичних підприємств в межах регіону та країни шляхом рівномірного охоплення всієї території надання послуг та всіх верств населення, можливість отримання туристичним підприємством державних замовлень та державних гарантій з метою підвищення ефективності ведення бізнесу, підвищення рівня плановості, прогнозованості ведення бізнесу, що призводить до економічної та соціальної стабільності, створення сприятливих умов для формування позитивного іміджу туристичного підприємства на основі його співпраці з державою.

Доцільність використання інструментів державно-приватного партнерства в діяльності туристичних підприємств визначає також К.В. Гороховська. В роботі «Імплементація державно-приватного партнерства В туристичний сектор як механізму економічного зростання регіону та країни загалом» [4] вона визначає розподіл відповідальності держави та приватного сектору у туристичній індустрії. На їі думку, держава привносить в соціальну діяльність туристичних компаній такі складові як: створення та забезпечення сприятливого середовища розвитку туристичної сфери, формування 
належних умов для стимулювання сталого розвитку туризму, здійснення спільних дослідницьких ініціатив співпраці з приватним сектором (іншими словами - фінансування наукових досліджень та пошукових робіт в сфері туризму). Водночас на основі державноприватного партнерства туристичні підприємства проводять реалізацію питань довкілля і соціальних питань держави та місцевих спільнот, сприяють збереженню культури, традицій та довкілля, залучають місцеві громади до розвитку туризму, розробляють заходи для здійснення навчання та перепідготовки фахівців, співпрацюють 3 урядом задля забезпечення безпеки туристів (табл. 2). Таке партнерство проводиться як на умовах створення змішаних підприємств, так і на умовах спільного менеджменту туристичних проєктів.

Таблиця 2

Розподіл відповідальності держави та приватних підприємств у туристичній індустрії [4]

\begin{tabular}{|c|c|}
\hline & IIp \\
\hline $\begin{array}{l}\text { 1. Розробка загального } \\
\text { бачення розвитку туризму } \\
\text { 2. Створення та забезпечення } \\
\text { сприятливого середовища } \\
\text { розвитку туристичної сфери } \\
\text { 3. Пропозиція } \\
\text { вільного капіталу та сприяння } \\
\text { інвестиціям } \\
\text { 4. Забезпечення } \\
\text { інфраструктури та ії утримання } \\
\text { 5. Формування } \\
\text { умов для стимулювання сталого } \\
\text { розвитку туризму } \\
\text { 6. Створення } \\
\text { законодавчої бази належни } \\
\text { 7. Здійснення належної } \\
\text { дослідницьких ініціатив співпраці } \\
\text { з приватним сектором спільних }\end{array}$ & 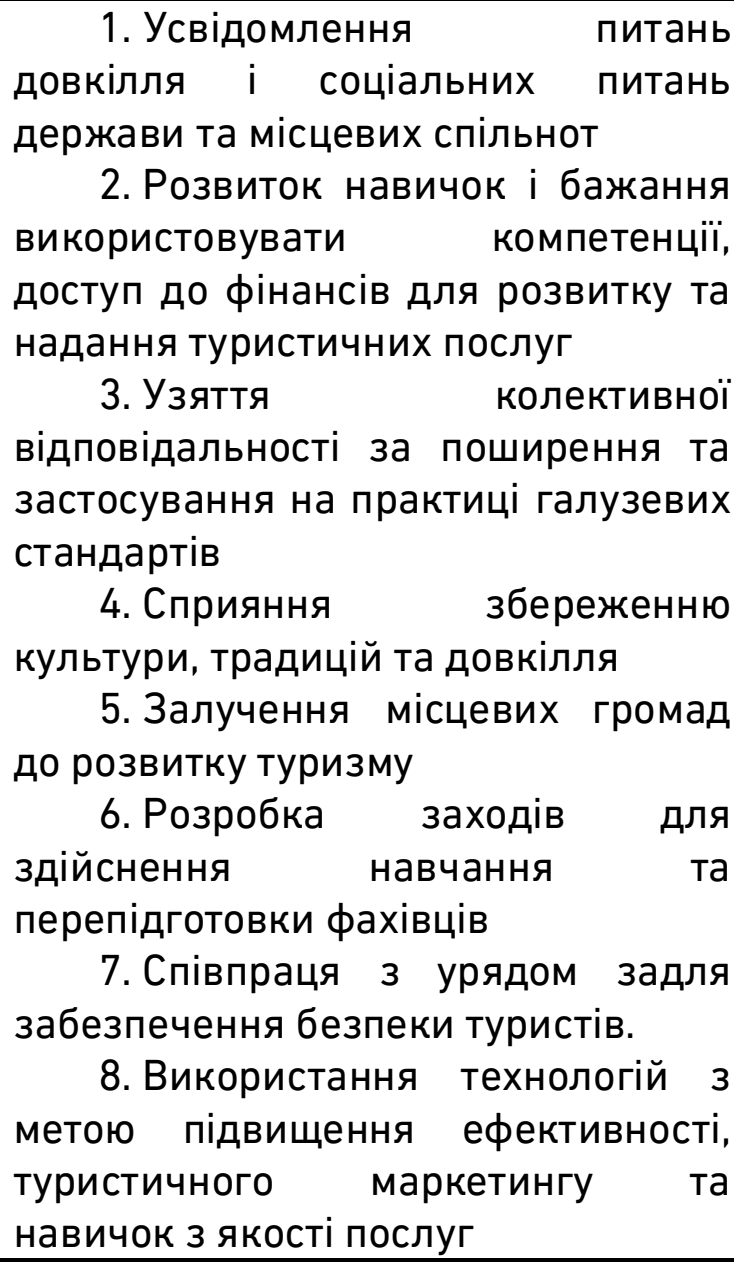 \\
\hline
\end{tabular}


Не зважаючи на рівень співпраці туристичного підприємства із державними органами влади, вони мають і самостійно вирішувати багато проблем соціально-економічного характеру в своїй діяльності. Так, Т. С. Незвещук-Когут в роботі «Проблеми та напрями підвищення ефективності управління якістю обслуговування на туристичних підприємствах» визначає, що при розробці системи управління якістю обслуговування на туристичному підприємстві має бути забезпечено органічну, планову взаємодію усіх іï підсистем на всіх етапах функціонування» [5]. Серед поданих автором напрямів можна виокремити цілу низку таких, що мають соціальну спрямованість. Основними з них є такі підсистеми управління:

- планування туристичних маршрутів, турів, удосконалення програм обслуговування;

- застосування економічних методів господарювання з метою підвищення якості обслуговування туристів, агентів та контрагентів;

- технологічна та технічна підготовка матеріальної бази до обслуговування туристів;

- організація процесів надання послуг і виконання програм обслуговування;

- систематичне планування та проведення аудиту якості;

- інноваційна діяльність;

- підготовка, підвищення кваліфікації кадрів;

- упровадження заходів із забезпечення якості праці персоналу;

- соціальний розвиток трудового колективу [5].

Важливою складовою діяльності сучасного туристичного підприємства є формування його бренду. О. Є. Гарбера визначає цінності туристичного бренду: функціональні, соціальні, емоційні, культурні, духовно-історичні, інноваційні. В його переліку соціальні цінності посідають важливе місце:

1. Функціональні цінності. Якість та доступність послуг: інфраструктура, якість товарів та послуг, що надаються місцевими підприємствами, унікальність території, рекреаційний потенціал тощо.

2. Соціальні цінності. Відчуття комфорту та затишку, безпеки та стабільності, атмосфера громадської та творчої свободи.

3. Емоційні цінності. Почутя та емоції, які виникають у відвідувачів та жителів міста.

4. Культурні цінності. Територіальна субкультура.

5. Духовно-історичні. Історико-культурна та історична спадщина території.

6. Інноваційні. Це розвиток науки та рівень інноваційного забезпечення виробництва, наявність передових підприємств, наукових розробок [6].

Безумовно, що соціальні чинники проявляються по різному у 
різних видах туризму. 3 метою виявлення сутності реалізації соціальних чинників туризму доцільно розглянуту основні ознаки видів туризму, що мають соціальні напрями, такі як освітній, оздоровчий, пізнавальний, дитячий туризм та ін. Значною мірою це питання досліджувала В.Є. Редько. На основі ії підходів ми пропонуємо власний погляд на диференціацію ознак різних видів туризму. Цю диференціацію подано в табл. 3.

Таблиця 3

Класифікаційні ознаки різних видів туризму

[складено автором на основі 7]

\begin{tabular}{|c|c|c|c|c|}
\hline № & Ознака & $\begin{array}{c}\text { Традиційний } \\
\text { туризм }\end{array}$ & Діловий туризм & $\begin{array}{c}\text { Соціальні } \\
\text { програми туризму }\end{array}$ \\
\hline 1 & $\begin{array}{c}\text { Джерело } \\
\text { фінансування } \\
\text { подорожі }\end{array}$ & Власні кошти & $\begin{array}{c}\text { Залучені кошти із } \\
\text { зовні (можливе } \\
\text { часткове } \\
\text { залучення власних } \\
\text { коштів) }\end{array}$ & $\begin{array}{c}\text { Власні кошти, } \\
\text { залучені кошти із } \\
\text { зовні (можливе } \\
\text { часткове } \\
\text { залучення } \\
\text { власних коштів) } \\
\end{array}$ \\
\hline 2 & Мета подорожі & $\begin{array}{c}\text { Різноманітна } \\
\text { Одна або } \\
\text { декілька цілей } \\
\text { Результат } \\
\text { подорожі } \\
\text { спрямований } \\
\text { безпосередньо } \\
\text { на туриста }\end{array}$ & $\begin{array}{c}\text { Комерційна } \\
\text { (ділова) } \\
\text { Чітко виражена } \\
\text { одна мета і } \\
\text { декілька } \\
\text { супутніх цілей } \\
\text { Результат } \\
\text { подорожі } \\
\text { спрямований на } \\
\text { суб'єкта } \\
\text { господарювання } \\
\text { (фірму, організацію } \\
\text { та ін.) й частково } \\
\text { на туриста }\end{array}$ & $\begin{array}{c}\text { Різноманітна } \\
\text { Одна або декілька } \\
\text { цілей } \\
\text { Результат } \\
\text { подорожі } \\
\text { спрямований } \\
\text { безпосередньо на } \\
\text { туриста, або } \\
\text { членів його сім"ї }\end{array}$ \\
\hline 3 & Результат & $\begin{array}{c}\text { Турист } \\
\text { задовольнив } \\
\text { власні потреби } \\
\text { (отримав нові } \\
\text { враження, } \\
\text { натхнення, } \\
\text { покращив } \\
\text { здоров'я та ін.) } \\
\text { й реалізував } \\
\text { мотиви } \\
\text { подорожі }\end{array}$ & $\begin{array}{c}\text { Турист реалізував } \\
\text { мотиви подорожі } \\
\text { на користь } \\
\text { суб'єкта } \\
\text { господарювання } \\
\text { (встановив, } \\
\text { налагодив } \\
\text { партнерські } \\
\text { стосунки, підписав } \\
\text { угоди та ін.) }\end{array}$ & $\begin{array}{c}\text { Турист } \\
\text { задовольнив } \\
\text { власні потреби } \\
\text { (отримав нові } \\
\text { враження, } \\
\text { натхнення, } \\
\text { покращив } \\
\text { здоров'я та ін.) й } \\
\text { реалізував мотиви } \\
\text { подорож }\end{array}$ \\
\hline
\end{tabular}


продовження табл. 3

\begin{tabular}{|c|c|c|c|c|}
\hline 4 & Тривалість & Середня & Коротка & Довготривала \\
\hline 5 & Періодичність & Відпустки, свята & $\begin{array}{c}\text { За рахунок } \\
\text { робочого часу }\end{array}$ & $\begin{array}{c}\text { Відпустки, свята, } \\
\text { за рахунок } \\
\text { робочого часу }\end{array}$ \\
\hline
\end{tabular}

Як можна побачити з таблиці, джерела фінансування подорожей в соціальному туризмі різноманітні. Вони включають власні кошти, залучені кошти ззовні, а також можливе часткове залучення власних коштів. Відрізняються від інших соціальні програми туризму і метою подорожей. Мета подорожей - різноманітна, вона містить одну або декілька цілей, результат подорожі спрямований безпосередньо на туриста, або членів його сім"ї. під час проведення такого туру із соціальною спрямованістю клієнт задовольняє власні потреби (отримує нові враження, натхнення, покращує здоров'я та ін.) й реалізує мотиви подорож.

Безумовно характеристики різних видів туристичних програм соціальної спрямованості відрізняються. Все більшою популярністю в нашій країні користується лікувально-оздоровчий туризм. Необхідно визначити, що популярність лікувально-оздоровчого туризму зростає у зв'язку декількома факторами. По-перше, в нашій країні існують усталені традиції лікувально-оздоровчого туризму. Під час існування СРСР значною мірою були реалізовані програми будівництва санаторіїв, будинків відпочинку, оздоровчих комплексів, які використовуються на теперішній час i $\epsilon$ основою, локальними центрами розвитку нових туристичних об'єктів, які використовують відомі бренди, лікувальну базу та розвинуту інфраструктуру. До таких санаторіїв-інфраструктурних центрів, навколо яких сформувалися нові центри надання оздоровчих послуг в різних куточках України, слід віднести відомі лікувальні установи: санаторії «Сонячне Закарпаття», «Червона Калина», «Карпати», «Миргород», «Куяльник», «Кирилівка» та багато інших. По-друге, реформа медицини, що нині проводиться в Україні, має завдання зберегти соціальну спрямованість системи охорони здоров'я і одночасно підвищити її ефективність та спрямувати на шлях комерціалізації. Це призводить до необхідності більш уважного ставлення громадянами до свого здоров'я, підвищення профілактичних оздоровчих заходів, формування здорового способу життя. Такі пріоритети допомагають досягти санаторії та інші лікувальні установи України. По-третє, якість послуг і сервіс в санаторіях України постійно підвищується, що дає можливість вітчизняним курортним підприємствам конкурувати 3 іноземними курортами і залучати на відпочинок не тільки туристів 3 України, але й з закордону. Однак, на думку авторитетних фахівців, можна визначити недоліки різного характеру, які заважають розвитку 
цієї сфери соціального туризму. Зокрема, І. І. Самойлова в статті «Державна політика щодо регулювання розвитку лікувальнооздоровчого туризму в Україні» визначає, що до основних перешкод розвитку лікувально-оздоровчого туризму доцільно віднести:

- незбалансованість соціальної та економічної ефективності використання рекреаційних ресурсів та необхідність їх збереження;

- слабку матеріальну базу багатьох об'єктів лікувальнооздоровчої інфраструктури;

- невідповідність переважної більшості оздоровчих закладів міжнародним стандартам;

- недостатню увагу органів влади до проблем розвитку лікувально-оздоровчої галузі, зокрема при розробці стратегій та програм економічного розвитку;

- низький рівень менеджменту та зношеність основних фондів;

- практичну відсутність інвестицій;

- низьку ефективність системи просування лікувальнооздоровчих продуктів на ринок;

- недосконалість нормативно-правової бази;

- недостатність методичної, організаційної, інформаційної та матеріальної підтримки суб'єктів підприємництва лікувальнооздоровчої індустрії з боку держави;

- недостатній рівень якості обслуговування у підрозділах харчування лікувально-оздоровчих закладів та недостатню забезпеченість висококваліфікованими спеціалістами [8].

Подолання таких перешкод зможе підвищити ефективність надання послуг в сфері лікувально-оздоровчого туризму. Однак найбільш важливим чинником розвитку лікувально-оздоровчого туризму є дотримання ідей сталого розвитку та зрушення соціальноекономічного розвитку країни в сторону «зеленої» економіки. Безумовним $є$ той факт, що напрями лікувально-оздоровчого туризму розвиватися не будуть в країні з поганою екологією, тому Україні необхідно дотримуватися всіх стандартів переходу до «зеленої» економіки, якщо вона прагне розвивати соціальні, лікувальнооздоровчі види туризму. Різні міжнародні організації по різному трактують підходи до «зеленої» економіки, однак в більшості такі підходи ідентичні. В табл. 4 представлено ключові аспекти концепції «зеленої» економіки, які формуються різними інституціями та авторами.

Основи поданої класифікації запропонував В.С. Мухін у статті «Концепція «зеленої економіки» та ї̈ застосування в курортнотуристичній сфері». 
Ключові аспекти концепції «зеленої» економіки

[розроблено на основі 9]

\begin{tabular}{|c|c|c|c|}
\hline № & $\begin{array}{c}\text { Організація/ } \\
\text { автор }\end{array}$ & $\begin{array}{c}\text { Назва } \\
\text { публікації }\end{array}$ & Ключові аспекти \\
\hline 1 & OECD & \begin{tabular}{|l} 
Towards \\
green \\
growth \\
(2011)
\end{tabular} & $\begin{array}{l}\text { Метою зеленої економіки є сприяння } \\
\text { економічному зростанню та розвитку, } \\
\text { одночасно забезпечуючи, щоб природні } \\
\text { активи продовжували надавати ресурси та } \\
\text { екологічні послуги, на які спирається наше } \\
\text { благополуччя. Економіка та навколишнє } \\
\text { середовище повинні взаємно зміцнювати } \\
\text { одне одного. Гарна економічна політика } € \\
\text { серцем зеленого зростання. Інновації } € \\
\text { ключовими. Вони сприяють стійкому } \\
\text { зростанню та забезпечують нові економічні } \\
\text { можливості }\end{array}$ \\
\hline 2 & $\begin{array}{l}\text { Програма } \\
\text { ООН з } \\
\text { навко- } \\
\text { лишнього } \\
\text { середовища } \\
\text { (UNEP) }\end{array}$ & $\begin{array}{l}\text { Towards a } \\
\text { green } \\
\text { economy } \\
(2011)\end{array}$ & $\begin{array}{l}\text { Зелена економіка є такою, що веде до } \\
\text { поліпшення добробуту та соціального } \\
\text { рівноправ'я, одночасно значно зменшуючи } \\
\text { екологічні ризики та екологічні дефіцити. } \\
\text { Перехід до зеленої економіки може бути } \\
\text { вигідним, дасть можливість об'єднати } \\
\text { здоровий спосіб життя } 3 \text { сильним } \\
\text { економічним зростанням. Економічне } \\
\text { зростання буде здоровим, міцнішим та } \\
\text { енергійнішим. Більше уваги приділяється } \\
\text { соціальним аспектам зеленої економіки }\end{array}$ \\
\hline 3 & $\begin{array}{l}\text { Світовий } \\
\text { банк } \\
\text { (World Bank) }\end{array}$ & $\begin{array}{l}\text { Inclusive } \\
\text { green } \\
\text { growth } \\
\text { (2012) }\end{array}$ & $\begin{array}{l}\text { Всеохоплююче зелене зростання - це шлях } \\
\text { до сталого розвитку. Зелений ріст - це } \\
\text { такий ріст, який базується на ефективному } \\
\text { використанні природних ресурсів, є чистим, } \\
\text { тому що мінімізує забруднення } \\
\text { навколишнього середовища та вплив на } \\
\text { навколишнє середовище, а також стійкий, } \\
\text { оскільки він не спричиняє природні } \\
\text { небезпеки. Сам ріст хороший, але він } \\
\text { повинен бути зеленим та достатньо } \\
\text { інтегрованим }\end{array}$ \\
\hline 4 & $\begin{array}{l}\text { Edward } \\
\text { Barbie }\end{array}$ & \begin{tabular}{|l} 
Різні \\
публікації
\end{tabular} & $\begin{array}{l}\text { Політикам необхідно домогтися масштабних } \\
\text { інноваційних та структурних перетворень. } \\
\text { Зростаючий екологічний дефіцит показує, } \\
\text { що сучасний економічний розвиток } \\
\text { нежиттєздатним }\end{array}$ \\
\hline
\end{tabular}


продовження табл. 4

\begin{tabular}{|c|c|c|c|}
\hline 5 & UNWTO & $\begin{array}{l}\text { Офіційний } \\
\text { сайт }\end{array}$ & $\begin{array}{l}\text { Ініціативи UNWTO: «Біорізноманіття», } \\
\text { «Заходи в сфері протидії зміні клімату», } \\
\text { «Глобальна ініціатива туризму», } \\
\text { «Енергоефективні рішення в готелях», } \\
\text { «Єдина планета», «Ефективність ресурсів у } \\
\text { туризмі», «Малі острові, що розвиваються», } \\
\text { «Спряння подорожам». }\end{array}$ \\
\hline
\end{tabular}

У відповідності до таких рекомендацій на макрорівні, туристичні підприємства формують власну політику роботи в сфері «зеленого» туризму. Туристичні підприємства 3 метою посилення та позиціювання свого бренду як «зеленого» підтримують на теперішній час заходи, що спрямовані на захист навколишнього середовища. В статті О.Ф. Грищенка «Дослідження перспектив використання зеленого маркетингу в туризмі» наводяться наступні заходи до яких приєднуються туристичні підприємства:

- очищення від забруднення або підтримання чистоти на певних територіях;

- охорона та захист флори та фауни;

- використання органічних, біорозкладних та/або перероблених матеріалів, які необхідні у процесі надання туристичної послуги;

- використання екологічно чистої енергії (таких як вітер, геотермальні джерела, сонячне світло тощо), технологій очищення і відновлення ресурсів;

- скорочення відходів виробництва (як енергії, так і матеріалів) та максимально непомітна інтеграція туристичного об'єкта у навколишнє середовище (наприклад, еко-дружні будівлі);

- використовування екологічно чистих об'єктів та методів, в тому числі користування екотранспортом (електромобілями, велосипедами), застосування натуральних та безпечних для навколишнього середовища миючих засобів, підтримка та розвиток органічного сільського господарства;

- навчання суспільства принципам та ідеям свідомого та екодружнього туризму [10].

На жаль, на теперішній вітчизняні корпорації України не входять до найбільш відомих світових брендів, які позиціонуються як найбільш просунуті у сфері зеленої економіки. Так, за матеріалами Forbs серед п'ятдесяти найбільш відомих «зелених» корпорацій світу дев'ять $€$ представниками туристичної сфери. Це такі корпорації як: Air Canada, Avis, Hilton Hotels, Home Depot, REl, InterContinental Hotels, 
JetBlue, United, Wyndham Hotels. Також у цьому переліку слід відзначити корпорації, які провадять свою діяльність у сферах, наближених до туризму, наприклад виробництво спортивних товарів, продуктів харчування, напоїв. Перераховані корпорації подано у табл. 5.

Таблиця 5

Тор-50 Зелених брендів, відібраних за споживацькою прихильністю [10]

\begin{tabular}{|c|c|c|c|c|c|}
\hline$№$ & Компанія & № & Компанія & № & Компанія \\
\hline 1 & Acer & 18 & Dunkin' & 35 & Nike \\
\hline 2 & Adidas & 19 & Epson & 36 & Panera \\
\hline 3 & Air Canada & 20 & Ford & 37 & Peet's \\
\hline 4 & Amazon.com & 21 & Hilton Hotels & 38 & Pepsi \\
\hline 5 & Apple & 22 & Home Depot & 39 & REI \\
\hline 6 & AT\&T & 23 & Honda & 40 & Samsung \\
\hline 7 & Aveda & 24 & HP & 41 & Starbucks \\
\hline 8 & Avis & 25 & Hyundai & 42 & Subway \\
\hline 9 & Brother & 26 & IBM & 43 & Tom's of Maine \\
\hline 10 & Budget & 27 & InterContinental & \multirow{2}{*}{44} & Toyotals \\
\hline 11 & Burt's Bees & 28 & JetBlue & 45 & Under Armour \\
\hline 12 & Canon & 29 & Kohl's & 46 & United \\
\hline 13 & Chic-fil-A & 30 & Konica-Minolta & 47 & Walmart \\
\hline 14 & Chipotle & 31 & Le Pain Quotidian & 48 & Whole Foods \\
\hline 15 & Coke & 32 & Macy's & 49 & Wyndham Hotels \\
\hline 16 & Dell & 33 & McDonald's & 50 & Zappos \\
\hline 17 & Discover Card & 34 & New Balance & & \\
\hline
\end{tabular}

Окремо як вид туризму, що має значний соціальний ефект, слід визначити освітній туризм. Значну увагу розвитку наукових підходів до проблем дослідження освітнього туризму присвятила Ганкіна М.С. У своїх працях вчена досліджувала функції освітнього туризму, його вплив на формування особистості, особливості освітніх туристичних програм залежно від віку та побажань клієнтів туристичних компаній, загальні підходи та конкретні механізми організації освітнього туризму. На основі аналізу наукової літератури авторка визначила найбільш привабливі та потенційно перспективні види освітнього туризму:

- ексурсійно-ознайомлювальні подорожі різними містами, природними зонами і країнами;

- навчальні поїздки з метою вивчення іноземної мови або тих чи інших загальноосвітніх та спеціальних предметів; 
- ознайомлювальні поїздки в установи, організації й на підприємства;

- наукові й навчальні стажування в установах, організаціях і на підприємствах;

- участь у семінарах, конференціях, з"їздах, конгресах, майстеркласах, мета яких - обмін досвідом і одержання нової професійно важливої інформації [11].

Як можна побачити, що із освітнім туризмом щільно пов'язаним $\epsilon$ діловий туризм. Зокрема В.Є. Редько визначає, що персоніфікований підхід від появи туристичного інтересу до формування вражень від подорожі забезпечують туристичні підприємства, що працюють в цій ніші ринку, спеціалізуючись, зокрема на MICE-туризмі:

- транснаціональні компанії(«American Express Global Business Travel», «BCD Travel», «Carlson Wagonlit», «Hogg Robinson Group»), «о спеціалізуються суто на МICE;

- українські монопрофільні MICE-підприємства («S\&T Group», «YanaEvent», «Life-Tour», «ART of MICE», «Окрайна»);

- багатопрофільні туристичні підприємства, в асортименті яких є MICE («Анекс Тур», «TUI Ukraine», «Корал», «Пегас Туристик» тощо).

Результати досліджень цього автора дозволяють зробити наступні висновки:

1. Аналіз тенденцій розвитку світового МICE-туризму дозволив визначити найпривабливіші дестинації, що володіють інфраструктурою, здатною задовольнити попит туристів у необхідній кількості і відповідній якості сервісу в умовах конкурентного ринку. Такими дестинаціями в 2018 р. є США, Німеччина, Іспанія.

2. Ефективність формування туристичних МІСЕ-потоків забезпечується завдяки використанню інноваційних технологій та інструментів туристичного онлайн супроводу для управління MICEподорожами, що потребує постійного вдосконалення.

3. Визначено характерні риси МІСЕ-туриста відповідно до джерел фінансування подорожі, її мети й очікуваних результатів, що вимагає дотримання політики подорожей компанії як самим туристом, так і туристичним підприємством.

4. MICE сприяє розвитку бізнесу, набуває все більшого масштабу, про що свідчить зростання кількості ділових заходів та грошових надходжень, для створення прогресивного, комфортного, гармонійного та безпечного існування людства. Вклад MICE в середовище існування не можливо не оцінити, адже він спрямований і на покращення середовища існування, і на суспільство в цілому [7]. 
MICE-туризм також несе значну соціальну спрямованість, як і будь-який іншій вид освітнього туризму. Він дозволяє працівникам корпорацій шляхом участі у корпоративних навчальних заходах підвищувати свою кваліфікацію, будувати кар'єрне зростання, інтегруватися в колектив менеджерів корпорації, самим корпораціям дозволяє підвищувати ефективність управління. Якщо інші види освітнього туризму наближають молодих людей до якісної освіти, підвищують їх самооцінку, розширяють світогляд та надають надію на перспективу зростання в майбутньому, то МICE-туризм вирішує конкретні цілі працівників компаній.

Практично всі види туризму, які пов'язано із туристичними програмами для дітей, ми можемо трактувати як соціальні. Дитячий туризм є окремою ланкою туристичної індустрії, що зумовлюється відповідальністю туристичних підприємств за безпеку життя, здоров'я дітей та надання їм якісних послуг. Дитячий туризм стосується також сфери освіти, культури, охорони здоров'я. В практиці дитячого туризм більш поширеним є придбання путівок, туристичних турів для дітей різних категорії державою, профспілками, благодійними організаціями. Цей фактор робить дитячий туризм привабливим для туристичних підприємств, а роботу в секторі туристичних послуг для дітей фінансово стабільною та прогнозованою. Сучасна економічна дійсність та несумлінна конкуренція, що трапляється на ринку туристичних послуг для дітей, призводить до окремих негативних факторів у зростанні дитячого туризму. Ці фактори, зумовлені, на думку Л. О. Івченко, наступним:

- бажанням табору зекономити на відсотках для агентств;

- появою мінітаборів, які впевнені, що зможуть впоратися 3 продажами без залучення агента;

- недовірою та необізнаністю батьків 3 інформацією щодо вартості туру в турагенції (помилкові думки про те, що вартість в агентстві більша ніж вартість у відділі продажів табору);

- неякісною роботою деяких агентів, що впливає на репутацію інших (помилки в документах, невиконання зобов'язань тощо) [12, C. 87].

Висновки. Таким чином, досліджуючи напрямки реалізації соціальних складових діяльності туристичних підприємств, слід визначити, що пріоритети розвитку туристичних підприємств та їх соціальної діяльності містяться в таких напрямах:

- вдосконалення нормативно-правової бази для створення сприятливих організаційно-правових умов розвитку туризму і рекреації; 
- соціальний розвиток трудових колективів туристичних підприємств;

- розширення спектру туристичних послуг, які носять соціальний характер, в т.ч. освітній, медичний (лікувальний), культурноісторичний туризм, туризм для дітей;

- приєднання туристичних компаній до ініціатив сталого розвитку.

Джерела фінансування подорожей в соціальному туризмі різноманітні. Вони включають власні кошти, залучені ззовні кошти, а також можливе часткове залучення власних коштів. Відрізняються від інших соціальні програми туризму і метою подорожей. Мета подорожі містить одну або декілька цілей, результат подорожі спрямований безпосередньо на туриста або членів його сімї. Під час проведення такого туру із соціальною спрямованістю клієнт задовольняє власні потреби (отримує нові враження, натхнення, покращує здоров'я та ін.) й реалізує мотиви подорожі.

Популярність лікувально-оздоровчого туризму зростає у зв'язку декількома факторами. По-перше, в нашій країні існують усталені традиції лікувально-оздоровчого туризму. Під час існування СРСР значною мірою були реалізовані програми будівництва санаторіїв, будинків відпочинку, оздоровчих комплексів, які використовуються i нині та є локальними центрами розвитку нових туристичних об'єктів, що використовують відомі бренди, лікувальну базу та розвинену інфраструктуру. По-друге, реформа медицини, що триває в Україні, має завдання зберегти соціальну спрямованість системи охорони здоров'я і одночасно підвищити її ефективність та спрямувати на шлях комерціалізації. Це призводить до необхідності більш уважного ставлення громадянами до свого здоров'я, підвищення профілактичних оздоровчих заходів, формування здорового способу життя. По-третє, якість послуг і сервіс в санаторіях України постійно зростає, що дає можливість вітчизняним курортним підприємствам конкурувати із іноземними курортами і залучати на відпочинок не тільки туристів з України, але й з закордону.

Безумовним $€$ той факт, що напрями лікувально-оздоровчого туризму розвиватися не будуть в країні з поганою екологією, тому Україні необхідно дотримуватися всіх стандартів переходу до «зеленої» економіки, якщо вона прагне розвивати соціальні, лікувально-оздоровчі види туризму. Різні міжнародні організації по різному трактують підходи до «зеленої» економіки, однак в більшості такі підходи ідентичні. 
Освітній туризм слід визначити окремо як вид туризму, що має значний соціальний вплив. Вітчизняні науковці досліджували функції освітнього туризму, його вплив на формування особистості, особливості освітніх туристичних програм залежно від віку та побажань клієнтів туристичних компаній, загальні підходи та конкретні механізми організації освітнього туризму.

Дитячий туризм є окремою ланкою туристичної індустрії, що зумовлює відповідальність туристичних підприємств за безпеку життя, здоров'я дітей та надання їм якісних послуг. Дитячий туризм стосується насамперед сфер освіти, культури, охорони здоров'я. В практиці дитячого туризму більш поширеним є придбання путівок, туристичних турів для дітей різних категорій державою, профспілками, благодійними організаціями. Цей фактор робить дитячий туризм привабливим для туристичних підприємств, а роботу в секторі туристичних послуг для дітей фінансово стабільною та прогнозованою.

1. Бондаренко М. П. Проблеми розвитку туристичних ринків. Інвестиції: практика та досвід. 2017. № 2. С. 87-91. 2. Узунов Ф. В. Управління розвитком державноприватного партнерства у реальному секторі: на прикладі туристичної галузі України. Економіка $i$ держава. 2014. № 2. С. 124-126. 3. Мешко Н. П., Гвоздєва А. Є. Особливості забезпечення ефективності управління попитом в туристичному бізнесі. Ефективна економіка. 2018. № 11. URL: http://www.economy.nayka.com.ua/?op=1\&z=6645 (дата звернення: 10.02.2020). 4. Гороховська К. В. Імплементація державно-приватного партнерства в туристичний сектор як механізму економічного зростання регіону та країни загалом. Ефективна економіка. 2016. № 9. ULR: http://www.economy.nayka.com.ua/?op=1\&z=5155 (дата звернення: 10.02.2020). 5. Незвещук-Когут Т.С. Проблеми та напрями підвищення ефективності управління якістю обслуговування на туристичних підприємствах. Ефективна економіка. 2015. № 4. ULR: http://www.economy.nayka.com.ua/?op=1\&z=3995 (дата звернення: 10.02.2020). 6. Гарбера О.Є. Територіальний брендинг як інструмент підвищення конкурентоспроможності туристичної дестинації. Ефективна економіка. 2016. № 10. ULR: http://www.economy.nayka.com.ua/?op=1\&z=5182 (дата звернення: 10.02.2020). 7. Редько В. Є., Оката Я. Г. Потенціал розвитку та організації MICE туризму. Ефективна економіка. 2019. № 12. URL: http://www.economy.nayka.com.ua/?op=1\&z=7498 (дата звернення: 10.02.2020). 8. Самойлова І. І. Державна політика щодо регулювання розвитку лікувальнооздоровчого туризму в Україні. Державне управління: удосконалення та розвиток. 2018. № 12. URL: http://www.dy.nayka.com.ua/?op=1\&z=1356 (дата звернення: 10.02.2020). 9. Мухін В. С. Концепція «зеленої економіки» та ії застосування в курортно-туристичній сфері. Ефективна економіка. 2019. № 3 . URL: http://www.economy.nayka.com.ua/?op=1\&z=6965 (дата звернення: 10.02.2020). 10. Грищенко О.Ф., Косторнова О.С. Дослідження перспектив використання зеленого маркетингу в туризмі. Ефективна економіка. 2017. № 8 . ULR: 
http://www.economy.nayka.com.ua/?op=1\&z=5723 (дата звернення: 10.02.2020). 11. Ганкіна М. С. Соціально-комунікативна функція туристичних підприємств на основі розвитку програм міжнародного освітнього туризму. Інвестиції: практика та досвід. 2017. № 10. С. 64-66. 12. Івченко Л. О., Кужиль С. В., Петренко М. В. Особливості організації дитячого туризму в Україні. Економіка та держава. 2019. № 1. С. 83-88.

\section{REFERENCES:}

1. Bondarenko M. P. Problemy rozvytku turystychnykh rynkiv. Investytsii: praktyka ta dosvid. 2017. № 2. S. 87-91. 2. Uzunov F. V. Upravlinnia rozvytkom derzhavnopryvatnoho partnerstva u realnomu sektori: na prykladi turystychnoi haluzi Ukrainy. Ekonomika i derzhava. 2014. № 2. S. 124-126. 3. Meshko N. P., Hvozdieva A. Ye. Osoblyvosti zabezpechennia efektyvnosti upravlinnia popytom $\mathrm{v}$ turystychnomu biznesi. Efektyvna ekonomika. $2018 . \quad$ №11. URL: http://www.economy.nayka.com.ua/?op=1\&z=6645 (data zvernennia: 10.02.2020). 4. Horokhovska K. V. Implementatsiia derzhavno-pryvatnoho partnerstva v turystychnyi sektor yak mekhanizmu ekonomichnoho zrostannia rehionu ta krainy zahalom. Efektyvna ekonomika. $2016 . \quad$ № $9 . \quad$ ULR: http://www.economy.nayka.com.ua/?op=1\&z=5155 (data zvernennia: 10.02.2020). 5. Nezveshchuk-Kohut T. S. Problemy ta napriamy pidvyshchennia efektyvnosti upravlinnia yakistiu obsluhovuvannia na turystychnykh pidpryiemstvakh. Efektyvna ekonomika. 2015. № 4. ULR: http://www.economy.nayka.com.ua/?op=1\&z=3995 (data zvernennia: 10.02.2020). 6. Harbera 0. Ye. Terytorialnyi brendynh yak instrument pidvyshchennia konkurentospromozhnosti turystychnoi destynatsii. Efektyvna ekonomika. 2016. № 10. ULR: http://www.economy.nayka.com.ua/?op=1\&z=5182 (data zvernennia: 10.02.2020). 7. Redko V. Ye., Okata Ya. H. Potentsial rozvytku ta orhanizatsii MISE turyzmu. Efektyvna ekonomika. 2019. № $12 . \quad$ URL: http://www.economy.nayka.com.ua/?op=1\&z=7498 (data zvernennia: 10.02.2020). 8. Samoilova I. I. Derzhavna polityka shchodo rehuliuvannia rozvytku likuvalnoozdorovchoho turyzmu v Ukraini. Derzhavne upravlinnia: udoskonalennia ta rozvytok. 2018. №12. URL: http://www.dy.nayka.com.ua/?op=1\&z=1356 (data zvernennia: 10.02.2020). 9. Mukhin V. S. Kontseptsiia «zelenoi ekonomiky» ta yii zastosuvannia v kurortno-turystychnii sferi. Efektyvna ekonomika. 2019. № 3. URL: http://www.economy.nayka.com.ua/?op=1\&z=6965 (data zvernennia: 10.02.2020). 10. Hryshchenko O. F., Kostornova O. S. Doslidzhennia perspektyv vykorystannia zelenoho marketynhu v turyzmi. Efektyvna ekonomika. 2017. № 8. ULR: http://www.economy.nayka.com.ua/?op=1\&z=5723 (data zvernennia: 10.02.2020). 11. Hankina M. S. Sotsialno-komunikatyvna funktsiia turystychnykh pidpryiemstv na osnovi rozvytku prohram mizhnarodnoho osvitnoho turyzmu. Investytsii: praktyka ta dosvid. 2017. № 10. S. 64-66. 12. Ivchenko L. O., Kuzhyl S. V., Petrenko M. V. Osoblyvosti orhanizatsii dytiachoho turyzmu v Ukraini. Ekonomika ta derzhava. 2019. № 1. S. 83-88. 


\section{DIRECTIONS OF REALIZATION OF TOURIST ENTERPRISES SOCIAL COMPONENTS}

In the article the directions of realization of social components of activity of tourist enterprises are considered, among which the authors define the following: social development of labor collectives of tourist enterprises; expanding the range of socially-owned tourist services, including educational tourism, medical (medical) tourism, cultural and historical tourism, tourism for children; joining tourism companies to sustainable development initiatives.

The first direction of social components realization is based on the improvement of organization of activity of the tourist company and relations within the labor collective. In the tourism industry, as in any other enterprise, social protection mechanisms should work and corporate social responsibility programs should be developed. Another direction of implementation of social components in the activity of tourism enterprises is the provision of tourist services that have a social focus. The sociality of individual tourism programs, especially in the field of children's tourism, is conditioned by state, grant funding. At present, such forms of financing are not as large as those of the planned economy, but they continue to exist and take on new forms. A separate direction of the social component of tourism enterprises is their activity in the environment of corporate support for sustainable development goals. Ideas, sustainable development programs aimed at improving the environment, reducing environmental and man-made risks make tourism more attractive overall and create separate tourism programs based on them.

The article determines that for the development of tourism enterprises in the direction of ensuring the realization of their social functions, in the future, the following tasks must be solved: formation of a modern regulatory framework for the definition and introduction of new technologies; provision of economic and legal information, aspiration for further integration into the world tourist community; forming in the general public a clear understanding of the importance of tourism as a priority for the economy; establishing partnerships between the government of the country and local authorities.

Keywords: directions; tourist; enterprises; social; services; sustainable development. 
Сазонец И. Л., д.э.н., профессор (Национальный университет водного хозяйства и природопользования, г. Ровно),

Джинджоян В. В., К.э.н., доцент (Частное высшее учебное заведение Днепровский гуманитарный университет, г. Днипро)

\section{НАПРАВЛЕНИЯ РЕАЛИЗАЦИИ СОЦИАЛЬНЫХ СОСТАВЛЯЮЩИХ ТУРИСТИЧЕСКИХ КОМПАНИЙ}

В статье рассмотрены направления реализации социальных составляющих деятельности туристических предприятий, среди которых авторами определены следующие: социальное развитие трудовых коллективов туристических предприятий; расширение спектра туристических услуг, которые носят социальный характер, В т.ч. образовательный, медицинский (лечебный), культурно-исторический туризм, туризм для детей; присоединение туристических компаний к инициативам устойчивого развития.

Ключевые слова: направления; туристические; предприятия; социальный; услуги; устойчивое развитие. 